\title{
Recent occurrence of moss Buxbaumia viridis (Bryophyta, Buxbaumiaceae) in the Klodzko region (Central and Eastern Sudetes, SW Poland)
}

\author{
Beata Cykowska \& Grzegorz Vončina
}

Recent occurrence of moss Buxbaumia viridis (Bryophyta, Buxbaumiaceae) in the Kłodzko region (Central and Eastern Sudetes, SW Poland). - Čas. Slez. Muz. Opava (A), 60:85-89, 2011.

\begin{abstract}
A rare epixylous moss, Buxbaumia viridis (Moug. ex Lam. \& DC.) Brid. ex Moug. \& Nestl., was searched at historical localities in the Kłodzko region, especially in Bialskie and Bystrzyckie Mts. The species was rediscovered at two localities in the upper part of the valley of Jedlnik stream on the east slope of Iwinka Mt. in Puszcza Śnieżnej Białki Nature Reserve. This paper presents data on autecology of $B$. viridis at one of the rediscovered localities as well as shows its current distribution in the Kłodzko region.

Key words: Bryophyta, Buxbaumia viridis, threatened species, protected species, distribution, Puszcza Śnieżnej Białki Nature Reserve, Śnieżnicki Landscape Park, Bialskie Mts., Sudety Mts., Poland
\end{abstract}

\section{Introduction}

Buxbaumia viridis is one of two species in the genus known from Europe (Hill et al. 2006) and Poland (Ochyra \& al. 2003). It is a boreal-montane moss which prefers primeval forests with coniferous wood on which it grows. The species is legally protected in Europe (Annex I of the Bern Convention; Annex II of the "Habitats-Fauna-Flora" directive) and is placed on the European Red-list for bryophytes (Schumacher \& Martiny 1995). It has been placed in the group of endangered species (E category) of the Red List of Polish mosses (Żarnowiec \&al. 2004) and was recognized as nationally protected in 2001 by the decree of the Ministry of the Environment in Poland (Anonymous 2001). The species requires protection in areas designated as the NATURA 2000 protected area (Stebel 2004), thus its current distribution and ecology is intensively studied in every country involved in this programme. Since 2007 some Polish Protected Areas, Polish National Forests and all historical localities of Buxbaumia viridis have been included in the monitoring of this species.

Buxbaumia viridis is widely distributed in Poland, however, its stations are very scattered and its populations are usually very scarce. It was found mainly in the mountains and their foothills, but it grows also in the southern uplands and the northern part of Poland (Szmajda $\&$ al. 1991). In recent time it was found on many localities in the Polish Carpathians: in Bieszczady Zachodnie Mts (Chachuła \& Vončina 2010); Beskid Sądecki range, Małe Pieniny range, Magura Spiska region (Cykowska 2008); Pieniny range (Vončina 2008); Gorce range (Vončina \& al. 2011) and the Tatras (Philippe \& Ochyra 2004; Vončina \& al. 2011). The species was found also on many localities in the Czech part of the Western Carpathians (Plášek \& Vacínová 2001; Plášek 2001, 2004, 2006) and in the Czech part of the Eastern Sudetes (Zmrhalová 2001) and only on one locality in the Polish Sudetes (Smoczyk \& Wierzcholska 2008). For the reason, it was very interesting to check whether $B$. viridis grows more often in the Polish side of the Sudetes, where in XIX century was very frequent (Szmajda \& al. 1991).

\section{Results}

During spring 2011 in the Polish side of the Central and Eastern Sudetes the species was searched at four published localities (Milde 1854, 1855; Berdowski 1979; Smoczyk \& Wierzcholska 2008) and many new places with fallen wood chose with cooperation of forest service in Kłodzko region. In spite of many potentially good conditions for existence of $B$. viridis in forests of nearly all entire Kłodzko region the species was rediscovered only on 
two places near historical locality published by Berdowski (1979) in Bialskie Mts. The current distribution of the species is presented on Fig. 3.

Newly discovered localities occur in the Puszcza Śnieżnej Białki Nature Reserve situated in the Eastern Sudetes within the area of the Śnieżnicki Landscape Park. The Nature Reserve with surface of 124.68 ha was established in 1953 in order to maintain and protect mountain beach forest Luzulo nemorosae-Fagetum with admixture of Acer pseudoplatanus L.and Picea abies (L.) H.Karst and alpine spruce forest. Two populations of Buxbaumia viridis was found on two spruce logs placed close to a small watercourse Jedlnik on east slope of Iwinka Mt. and growing in the similar conditions like the species found on the localities in Carpathians. Details of both new localities are provided below:

AtMOS grid square: Fb 48 - EASTERN SUDETES, BIALSKIE MTS.: NE slope of Iwinka Mt. in Puszcza Śnieżnej Białki Reserve:

1. altitude $990 \mathrm{~m}$ a.s.1., 50²' $14^{\prime} 30.5^{\prime \prime} \mathrm{N}, 16^{\circ} 59^{\prime} 30.7^{\prime \prime} \mathrm{E}$, on decaying spruce log above Jedlnik stream in the beech forest with admixture of Acer pseudoplatanus and Picea abies, 3 capsules. Date of observation: 21 May 2011, by G. Vončina \& B. Cykowska. Associated species: Cephalozia bicuspidata (L.) Dumort., Dicranum scoparium Hedw., Herzogiella seligeri (Brid.) Z.Iwats., Lepidozia reptans (L.) Dumort., Lophocolea heterophylla (Schrad.) Dumort., Orthodicranum montanum (Hedw.) Loeske, Polytrichastrum formosum (Hedw.) G.L.Sm., Rhizomnium punctatum (Hedw.) T.J.Kop., Tetraphis pellucida Hedw. Vascular plants: Oxalis acetosella L., Salix sp. (juv.).

2. altitude $1010 \mathrm{~m}$ a.s.1., 50²' $14^{\prime} 30.5^{\prime \prime} \mathrm{N}, 16^{\circ} 59^{\prime 27.9 "} \mathrm{E}$, on decaying spruce log above Jedlnik stream in the beech forest with admixture of Acer pseudoplatanus and Picea abies, 8 +1 capsules. Date of observation: 21 May 2011, by B. Cykowska \& G. Vončina. Associated species: Dicranum scoparium, Herzogiella seligeri, Lophocolea heterophylla, Polytrichastrum formosum, Rhizomnium punctatum (Hedw.) T.J.Kop., Sanionia uncinata (Hedw.) Loeske.

\section{Conclusions}

Only found in the Polish side of the Sudetes populations of Buxbaumia viridis from the Bialskie Mts. occurred in the area under strict protection similarly like the majority of species localities in the Carpathians (Cykowska 2008; Vončina 2008; Chachuła \& Vončina 2010; Vončina \& al. 2011). The species was not rediscovered on any locality situated in a managed forest. It seems to be an important information that the strict protection is the best way to maintain the sites for B. viridis. New information about locality of Buxbaumia viridis in Bialskie Mts. confirm a conclusion of Wierzcholska \& Plášek (2006), that Bialskie Mts. are exceptional bryological area.

Acknowledgements:We wish to thank the Regional Direction of Environment Protection for a permission to search Buxbaumia viridis in the protected area of the Puszcza Śnieżnej Białki Nature Reserve, Stronie Śląskie Forest District for assent to entrance into the internal tracks and Bystrzyca Kłodzka Forest District and Stronie Śląskie Forest District for permission to carry out the research in their administrated forests. We would like to especially express our thanks to the forester Piotr Traczewski for his help during the field works and for having us in forester's lodge in Lasówka. This scientific work was partly supported by the Institute of the Nature Conservation Polish Academy of Science in Kraków and the Ministry of Education and Science of the Polish Government for the 2010-2014 (grant No. N N303 572038).

\section{References}

Anonymous (2001): Rozporządzenie Ministra Środowiska z dnia 11 września 2001 roku w sprawie określenia listy gatunków roślin dziko występujących objętych ochroną gatunkową ścisłą i częściową [“Order of the Minister of the Environment on 11 September 2001 listing the wild plant species strictly and partly protected by law”]. (Dziennik Ustaw Nr 106, pozycja 1179, 2001) [“Official Gazette Announcing Current Legislation" No. 106, item 1179, 2001”]. 
Berdowski W. (1979): Nowe stanowiska rzadszych gatunków mchów na Dolnym Śląsku i Opolszczyźnie.Acta Universitatis Wratislaviensis 304, Prace Botaniczne, 22: 3-18.

Chachuła P. \& Vončina G. (2010): The discovery of Buxbaumia viridis (Bryophyta, Buxbaumiaceae) in the Bieszczady National Park.- Roczniki Bieszczadzkie, 18: 419-423.

Cykowska B. (2008): New records of Buxbaumia viridis (Bryophyta, Buxbaumiaceae) in the Polish Carpathians. In: Stebel A. \& Ochyra R. (eds): Bryophytes of the Polish Carpathians. Sorus, Poznań: pp. 251-255.

Hill M. O., Bell N., Bruggeman-Nannenga M. A., et al. (2006): An annotated checklist of the mosses of Europe and Macaronesia.- Journal of Bryology, 28: 198-267.

Milde J. (1853): Ueber meine Excursionen im Sommer 1853.- Jahresbericht der Schlesischen Gesellschaft für vaterländische Cultur, 31: 164-168.

- (1854): Bemerkungen über schlesische Cryptogamen.- Jahresbericht der Schlesischen Gesellschaft für vaterländische Cultur, 32: 64-71.

Ochyra R., Żarnowiec J., Bednarek-Ochyra H. (2003): Census catalogue of Polish mosses. In: Mirek Z. (ed.). Biodiversity of Poland. 3. W. Szafer Institute of Botany, Polish Academy of Sciences, Kraków.

Philippe M. \& Ochyra R. (2004): Occurrence of the moss Buxbaumia viridis (Bryopsida, Buxbaumiaceae) in the Tatras National Park (Poland). In: Stebel, A. \& Ochyra R. (eds): Bryological studies in the Western Carpathians. Sorus, Poznań, pp. 29-36.

Plášek V. \& Vacínová I. (2001): Příspěvek k poznání ekologie a populační biologie mechu Buxbaumia viridis.- Časopis Slezského Zemského Muzea, Ser. A, 50: 11-19.

Plášek V. (2001): Příspěvek k rozšíření mechu Buxbaumia viridis v Moravskoslezských Beskydech.- Časopis Slezského Zemského Muzea, Ser. A, 50: 1-3.

- (2004): The Moss Buxbaumia viridis (Bryopsida, Buxbaumiaceae) in the Czech part of the Western Carpathians - distribution and ekology. In: Stebel, A. \& Ochyra R. (eds), Bryological studies in the Western Carpathians. Poznań: Sorus, pp. 37-44.

- (2006): Výskyt mechu Buxbaumia viridis v NPR Stužica (NP Poloniny).- Bull. Slov. Bot. Spoločn., Bratislava, 28: 57-59.

Schumacker R. \& Martiny P. (1995): Red Data Book of European bryophytes. Part. 2: Threatened bryophytes in Europe including Macaronesia. The European Committee for Conservation of Bryophytes, Trondheim: pp. 29-193.

Smoczyk M. \& Wierzcholska S. (2008): Wyniki badań botanicznych jako podstawa do rozszerzenia sieci obszarów Natura 2000 w zachodniej części Ziemi Kłodzkiej. In: Furmankiewicz M. \& MastalskaCetera B. (eds), Problemy wdrażania sieci Natura 2000 na obszarze Sudetów. Muzeum Przyrodnicze w Jeleniej Górze, Jelenia Góra. pp. 101-117.

Stebel A. (2004): Buxbaumia viridis, Bezlist okrywowy. In: Sudnik-Wojcikowska, B. \& WerblanJakubiec H. (eds): Gatunki roślin. Poradniki ochrony siedlisk i gatunków Natura 2000 - podręcznik metodyczny ["Plant species. Handbook of habitats and species protection Natura 2000 - a guidebook"]. 9. Ministerstwo Środowiska, Warszawa: pp. 29-32.

Szmajda P., Bednarek-Ochyra H., Ochyra R. (1991): M 639. Buxbaumia viridis (DC.) Moug. \& Nestl. In: Ochyra, R. \& Szmajda P. (eds): Atlas of the geographical distribution of spore plants in Poland. Series V. Mosses (Musci). 7. W. Szafer Institute of Botany of the Polish Academy of Sciences and Adam Mickiewicz University, Krakow - Poznań: pp. 47-52 + 1 map.

Vončina G. (2008): The occurrence of Buxbaumia viridis (Bryophyta, Buxbaumiaceae) in the Pieniny National Park (Poland). In: Stebel, A. \& R. Ochyra (eds): Bryophytes of the Polish Carpathians. Sorus, Poznań: pp. 243-250.

Vončina G., Cykowska B., Chachuła P. (2011): Rediscovery of Buxbaumia viridis (Bryophyta, Buxbaumiaceae) in the Tatras and Gorce in the Polish western Carpathians. In: Stebel A. \& R. Ochyra (eds): Chorological studies in the Polish Carpathians. Sorus, Poznań: (in press).

Wierzcholska S. \& Plášek V. (2006): The Bialskie Mts (Eastern Sudetes, Poland), an extraordinary bryological area.- Biodiversity Research and Conservation, 3-4: 369-372.

Zmrhalová M. (2001): Přrspěvek k rozšíření mechu Buxbaumia viridis (Mough. ex Lam. et DC.) Brid. ex Mough. et Nestl. v Hrubém Jeseníku, Rychlebských horách a na Králickém Sněžíku.- Časopis Slezského Zemského Muzea, Ser. A, 50 (supl.): 4-8.

Żarnowiec J., Stebel A., Ochyra R. (2004): Threatened moss species in the Polish Carpathians in the light of a new Red-list of mosses in Poland. In: Stebel, A. \& Ochyra R. (eds), Bryological studies in the Western Carpathians. Sorus, Poznań: pp. 9-28. 

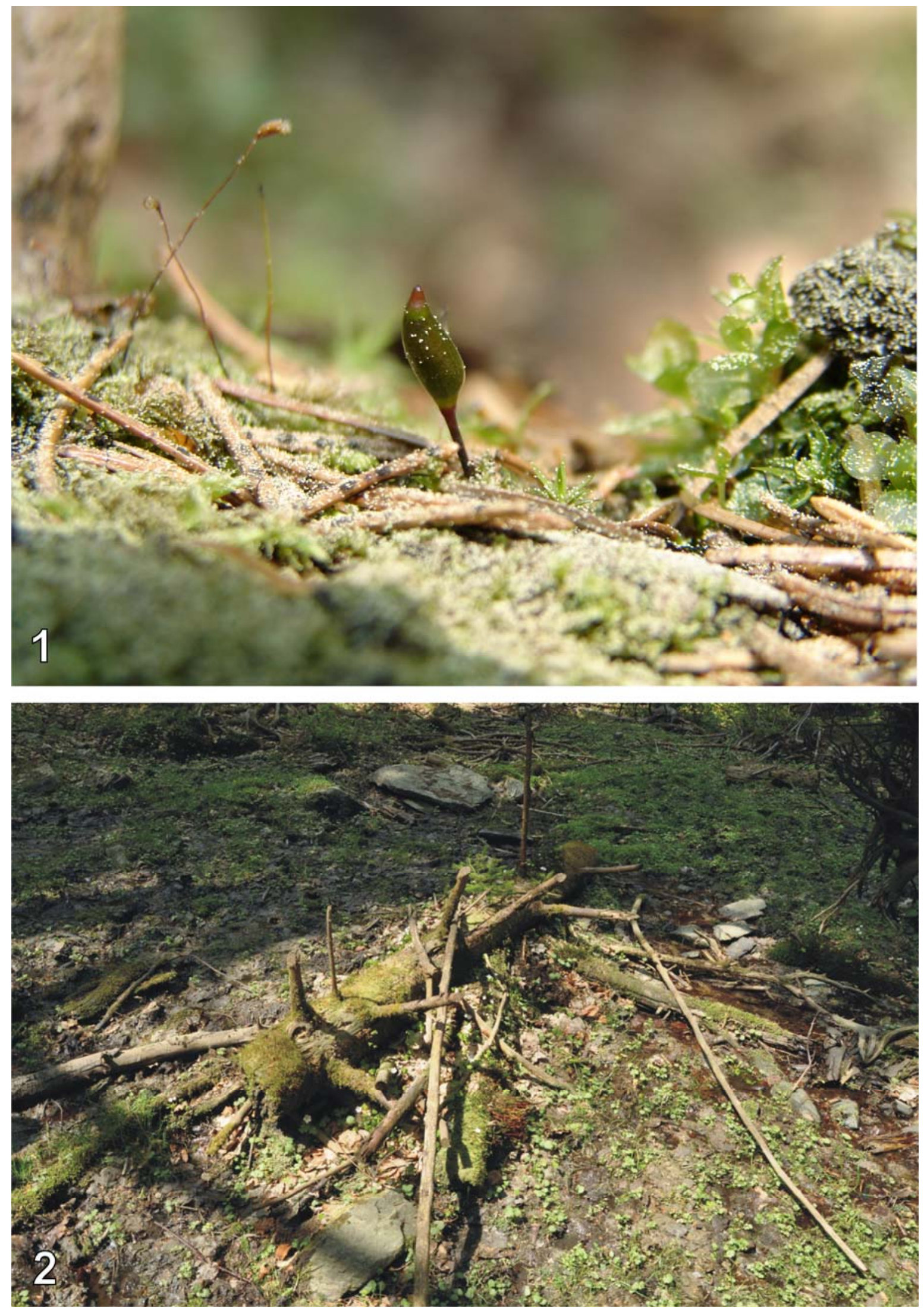

Fig 1-2: 1 - Habit of the sporophyte of Buxbaumia viridis in Puszcza Śnieżnej Białki Reserve in the Bialskie Mts. (photo by G. Vončina, 21 May 2011). 2 - A log with Buxbaumia viridis in Puszcza Śnieżnej Białki Reserve in the Bialskie Mts. (photo by B. Cykowska, 21 May 2011). 


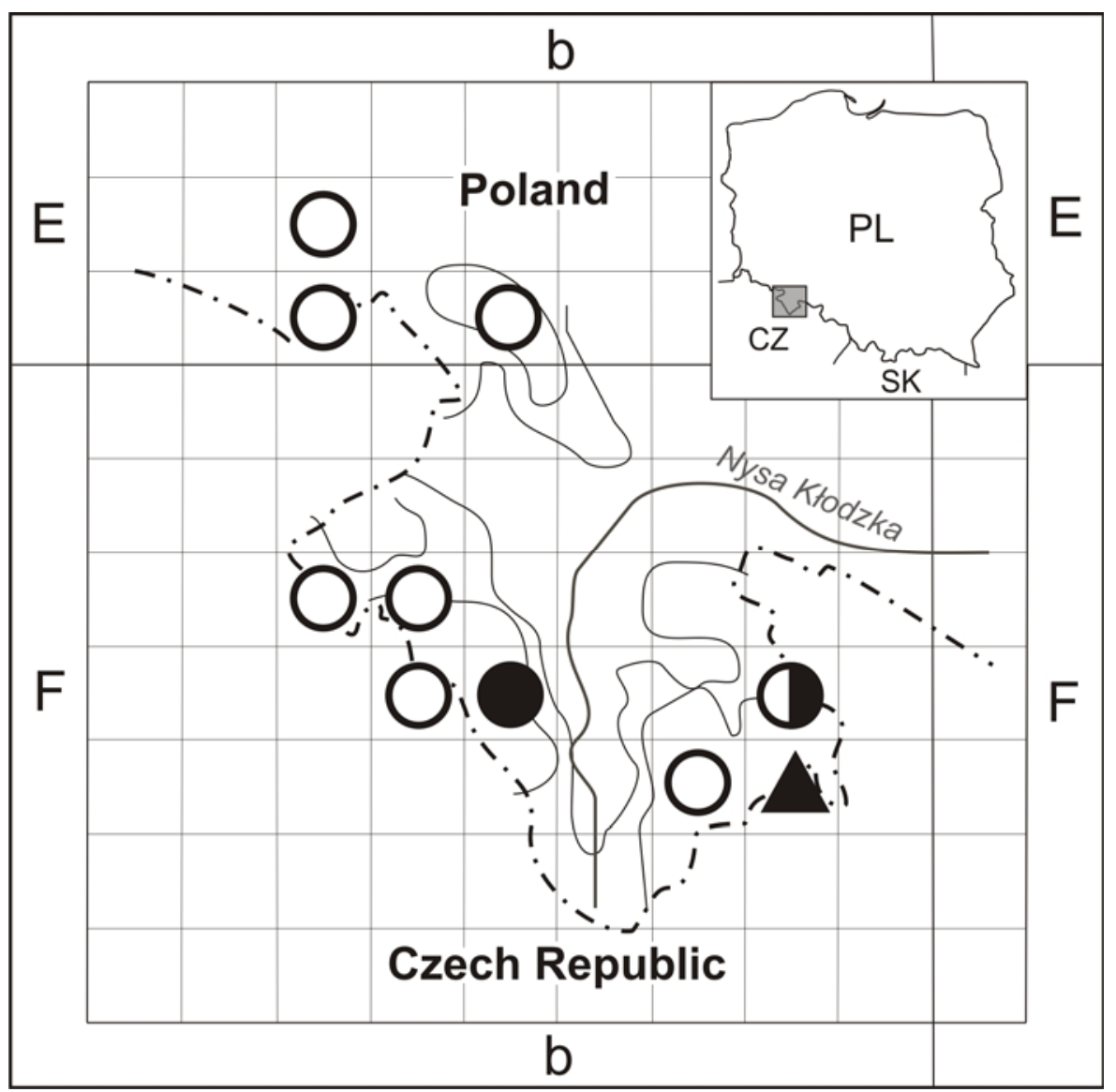

Fig 3: Distribution of Buxbaumia viridis in the Kłodzko region (Central and Eastern Sudetes); O - pre-1900 localities; - 1901-1950 localities, - locality in Młoty published by Smoczyk \& Wierzcholska (2008), $\boldsymbol{\Delta}$ rediscovered stations.

Authors' adresses: Beata Cykowska, Laboratory of Bryology, W. Szafer Institute of Botany, Polish Academy of Sciences, Lubicz 46, PL-31-512 Kraków, Poland; e-mail: b.cykowska@botany.pl

Grzegorz Vončina, Pieniny National Park, ul. Jagiellońska 107B, 34-450 Krościenko nad Dunajcem; e-mail: gvoncina@poczta.onet.pl 